\title{
Understanding the Phenotypic Diversity and Ecological Distribution of Noug (Guizotia abyssinica) for Its Improvement and Conservation
}

\author{
Misteru Tesfaye $^{1^{*} \quad \text { Abel Teshome }^{2} \quad \text { Hannes Dempewolf }}{ }^{3}$ \\ 1. Ethiopian Institute of Agricultural Research, Holetta Agricultural Research Center P.O. Box.31, Holetta \\ 2. Departments of Biology, Addis Ababa University, P.O. Box 1176, Addis Ababa \\ 3. Global Diversity Trust, 53115, Bonn, Germany
}

\begin{abstract}
Noug (Guizotia abyssinica) is an important oil crop to Ethiopia where it has been cultivated as source of edible oil since antiquity. Despite the country harbors ample genetic resources of noug, diversity and ecological information useful for its improvement and conservation is very limited. The aim of this study was to assess noug phenotypic diversity along with its ecological distribution based on morphological characters and environmental data. During 2009/10 cropping season, one hundred noug accessions which were collected from different parts of Ethiopia were planted augmented with four standard checks at two testing sites namely Holetta and Ginchi. Diversity and correlation analysis followed by principal component analysis were conducted for agro-morphological traits using statistical software package $R$ v. 2.10.0/1.17-3. Non-metric multidimensional scaling (NMDS) analysis was made to understand which environmental variable that drives phenotypic diversity. Ecological niche modeling using Maxent software programme was also employed to comprehend the agro-ecological niche of noug. According to diversity analysis of phenotypic data, most traits showed considerable diversity within and among populations. The correlation analysis revealed that the number of seeds per plant and number of heads was positively correlated with the number of primary or secondary branches. A significant positive correlation was also obtained between the number of heads and number of seed per plant, and 1000 seed weight and the number of seed per plant. Seven noug populations (N07027, N07028, N07001, N08009, N08002, N08048 and N07009) were found to be unique populations. NMDS analysis showed precipitation was the most important environmental factor that drives noug phenotypic diversity. Ecological niche modeling indicates that the northern and western parts of Ethiopia were found to be the dominant noug niches which accounts $>80 \%$ of the total noug growing areas. Kenya followed by Eritrea were other African countries where the crop was grown in some pocket area. A number of noug populations useful for breeding efforts were also identified. In conclusion, noug populations variable for many traits have been identified and such variability is useful for its improvement and ex situ conservation effort of the crop.
\end{abstract}

Keywords: - Noug (Guizotia abyssinica), genetic diversity, noug improvement and conservation.

DOI: $10.7176 / \mathrm{JNSR} / 9-5-06$

Publication date:March $31^{\text {st }} 2019$

\section{Introduction}

Noug (Guizotia abyssinica) is an oil-seed crop, indigenous to Ethiopia, where it is the major source of edible oil and holds significant promise for improving rural livelihoods. Noug oil is the most preferred cooking oil and thus most oil mills located in the major cities or small towns of Ethiopia extract noug oil. In addition to its oil, noug is an important source of seed proteins, carbohydrates, minerals, vitamins and fiber that significantly contributes to the human dietary intake of resource-poor farmers (Tesfaye Deme et.al. 2017). Noug is used in intercropping systems and can grow on waterlogged, marginal and poor soils where most other crops fail to grow. The noug seed is consumed after being processed in various forms for its unique nutritional, medicinal and cultural values (Geleta et al. 2002). Despite its enormous importance to Ethiopian farmers, the national average seed yield of noug landraces is not more than 9Q/ha (CSA 2016), which is significantly lower than that of improved varieties of other edible oil crops, such as sunflower and oilseed brassicas. The main aim of noug improvement efforts in Ethiopia is, therefore, provision of high yielding noug cultivars to farmers through breeding using the available genetic resources along with suitable crop management practices.

Ethiopia is considered the center of origin and domestication of noug (Murthy, Hiremath \& Salimath, 1993). It is believed that the country possess wide genetic resources of noug which are conserved in gene banks or maintained by farmers. Utilization of the existing gene pool of any crop though evaluation of its germplasm is the base for its improvement (Rauf et.al., 2010). The first major characterization and evaluation scheme of noug were conducted in 1982 and 1983 using 243 and 127 noug accessions, respectively which were collected from major regions of Ethiopia, Gojam Gondor, Shewa Wellega and Wello in 1981. These accessions were evaluated at Holetta Agricultural Research Center for various agro-morphological and quality traits (Getinet and Sherma, 1996). It was also possible to group these accessions in to different maturity groups such as early flowering type (75 -90 days), medium groups (105-120 cm) and late groups (105-120 days). Based on these accessions some diversity 
studies were conducted by Genet and Ketema (2000) that indicated more diverse noug population found in major noug growing regions of Ethiopia namely Wellega, Gojjam, Shewa and Gondor. Recent studies on Ethiopian noug populations revealed high levels of genetic variation for different agro morphological traits (Geleta et al. 2007, 2008). According to the recommendations of the above authors, additional collections missions are necessary to exploit the gene pool of noug so that the wealth genetic diversity of the crop will be exploited for its improvement and conservation. Therefore, the objective of this study was to comprehend the genetic diversity of noug germplasms based on morphological characters and its ecological distribution.

\section{Materials and methods}

Noug collections were made in the central, western and northern part of Ethiopia during the noug harvest seasons of 2007 and 2008. The collection targeted to areas where noug has either not been collected or has never been collected before (Table 1 and Fig 1). A GPS device was used to record the precise geographical location of each collection. A total of 116 accessions were planted on the $15^{\text {th }}$ and $17^{\text {th }}$ of July 2010 at Holetta and Ginchi, respectively augmented with four checks in four blocks each containing 29 accessions. Each accession sown with $0.3 \mathrm{~m}$ distance between two rows of the same accessions and $0.6 \mathrm{~m}$ distance between plots of different accessions. Each plot was phenotyped using 10 randomly selected plants in terms of plant height, number of primary and secondary branch, leaf width, and number of seed per plant, head size, number of head per plant, number of seed per head and 1000 seed weight. Environmental data were taken for all collecting locations using the publicly available Worldclim/Bioclim dataset (http://www.worldclim.org/bioclim), which contains a set of 19 environmental variables, including precipitation and temperature data. Data were transformed using square (height), square root (leaf width, number of secondary branches and seeds per head) or logarithmic (number of heads, number of primary branches, head size and seeds per plant) to meet the assumptions of normality.

Phenotypic diversity for morphological traits was analyzed considering both testing sites. Pearson's partial correlation analysis was used to measure phenotypic correlations while the level of correlations of traits with different environmental variables was investigated using a non-metric multidimensional scaling (NMDS). Principal component analysis (PCA) was also performed to identify unique populations from the noug populations under study. Statistical package $R$, version 2.10.0 ( $R$ Development Core Team 2011) and version 1.17-3 (Oksanen et al. 2010) were used for the above analysis. Ecological niche modeling technique was employed using the software Maxent to model noug's agro-ecological niche both for Ethiopia and Africa.

\section{Results and discussion}

\subsection{Phenotypic diversity and correlation}

According to diversity analysis of phenotypic data, most traits showed considerable diversity within and among populations as shown in Fig.1, which displays most of the traits assessed in both locations (Holetta and Ginchi). Conducting phenotypic characterization at two different sites allowed us to assess the level of phenotypic plasticity which was found to be high for most traits.

In addition to the diversity study, phenotypic correlation among agronomically important traits was also analyzed using Pearson's Partial Correlation Analysis. This result showed that significant positive correlation between the number of primary/secondary branches and the number of heads and seed per plant at both sites (Holetta and Ginchi). A significant positive correlation was also observed between the number of head and number of seed per plant, and 1000 seed weight and the number of seed per plant (Table 2). This implies that unfavourable phenotypic correlations were not found in noug and thus the plant architectural constraints could not be a factor to hider breeding noug for larger and more seed. Correlations between 1000 seed weight and the number of seed per head and the number of seed per plant were not significant, and showed different trends in the two sites. This might due to the slight environmental difference between the two locations where Ginchi is found at lower altitude (by 115 meter), receive less rainfall (250 $\mathrm{mm}$ mean rainfall) and has heavier soil than Holetta.

\subsection{Principal component analysis}

According to the principal component, noug populations such as N07027 and N07028 collected from Benishangul Gumuz, N07001, N08009 and N08002 from Amhara, N08048 and N07009 from Oromia regions were found to be the most extreme outliers that indicates their unique nature or differ in genetic make-up from other populations (Fig. 3). These noug populations were found from previously uncollected districts of the above regions.

\subsection{Non-metric multidimensional scaling (NMDS) analysis}

Among the 19 environmental variables that mostly correlated with the observed spread phenotypic diversity is precipitation. As we observed from NMDS analysis, three precipitation variables: - i) Precipitation of Wettest Quarter, ii) Precipitation of Wettest Month and iii) Precipitation of Coldest Quarters are highly correlated with each other that is why they seem to be align in parallel as shown in the figure 4 . This indicates that the level of precipitation during the growing season of noug is likely the most important environmental factor that drives noug 
phenotypic diversity. The analysis of NMDS is also revealed that precipitation in the wettest quarter seems to be the environmental factor most strongly correlated with phenotypic diversity. This indicates that there is likely local adaptation to different precipitation regimes.

\subsection{Distribution and area coverage of noug}

Based on ecological niche modeling using locations of geo-referenced noug populations and GIS data, noug is dominantly distributed in the northern and western part of the Ethiopia where the crop grown with altitude ranges from 750-3397m a.s.l (Fig 5 and Table 1). Oromia region followed by Amara occupy large area for noug production whereby the former region cover an average area of 154,833 ha while the latter 100434 ha during the last ten years (Fig 6.) According to geospatial map of the continent Africa, noug is assumed to be grown in other Africa countries such as Kenya and Eritrea (Fig 7). Such modeling attempts are important in the context of promoting and facilitating the conservation and use of neglected and underutilized crops like noug.

\subsection{Towards a breeding program for noug}

A wide range of data for important traits of noug was generated and noug populations relevant to the breeding efforts were identified based on their useful agronomic traits (Table 3). A total of 100 new accessions were obtained and such collections significantly enhance the ex situ collection in Ethiopia. It should be noted that there are some additional areas in Ethiopia that could not be addressed due to their remoteness and that might harbor further interesting materials.

\section{Conclusions}

In general, this study has clearly shown that there is a considerable amount of noug diversity present in farmers' fields that can be used for breeding program. Such diversity was mainly within population which implies the need of on-farm conservation efforts in all major noug growing regions. It could be suggested that future breeding efforts of noug should focus on strong selection for more heads and larger seeds to boost its yield in addition to other relevant traits such as synchronous flowering and reduced shattering. Germplasm evaluation would result in identification of valuable noug germplasms with useful agronomic traits. It will be important for noug breeders to be aware of the high levels of phenotypic plasticity of the crop, which requires testing of the cultivars in a wide variety of different environments.

\section{References}

CSA-Central Statistical Agency (2015/16) Area and production of major crops. Statistical Bulletin 583, Addis Ababa.

Geleta M, Asfaw Z, Bekele E, Teshome A (2002). Edible oil crops and their integration with the major cereals in North Shewa and South W elo, central Highlands of Ethiopia: an ethnobotanical perspective. Hereditas 137:29-40.

Geleta, M. 2007. Genetic diversity, phylogenetics and molecular systematics of Guizotia. Phd Thesis. Department of Plant Protection Biology, Swedish University of Agricultural Sciences, Alnarp.

Geleta, M., T. Bryngelsson, E. Bekele, and K. Dagne. 2008. Assessment of genetic diversity of Guizotia abyssinica (L.f.) Cass. (Asteraceae) from Ethiopia using amplified fragment length polymorphism. Plant Genetic Resources 6:41-51.

Getinet Alemaw and Sherma, S.M. (1996). Niger. Guizotia abyssinica (L.f) Cass. Promoting the Conservation and use of Under-utilized and Neglected Crops. Institute of Plant Genetics and Crop Plant Research, International Plant Genetic Resource Institute, Gatersleben, Rome.

Murthy, H.N., Hiremath, S.C. \& Salimath, S.S (1993). Origin, evolution and genome differentiation in Guizotia abyssinica and its wild species. Theoretical and Applied Genetics 87, 587-592.

Oksanen, J., F. G. Blanchet, R. Kindt, P. Legendre, R.B. O'Hara, G.L. Simpson, P. Solymos, M. Henry, H. Stevens, and H. Wagner. 2010. vegan: Community Ecology Package. R package version 1.17-3. http://CRAN.Rproject.org/package $=$ vegan

$R$ - Development Core Team. 2011. R: A Language and Environment for Statistical Computing. R Foundation for Statistical Computing. Vienna, Austria: http://www.R-project.org

Rauf S, da Silva JT, Khan AA, Naveed A. (2010.) Consequences of plant breeding on genetic diversity. Int J Plant Breed. 41:1-21.

Tesfaye Deme, Gulelat D. Haki, Nigussie Retta, Ashagrie Woldegiorgis and Mulatu Geleta (2017). Mineral and Anti-Nutritional Contents of Niger Seed (Guizotia abyssinica (L.f.) Cass. Linseed (Linum usitatissimum L.) and Sesame (Sesamum indicum L.) Varieties Grown in Ethiopia

Tsige Genet \& Ketema Belete, 2000. Phenotypic diversity in the Ethiopian noug germplasm. African Crop Science Journal 8: 137-143. 


\section{Authors Bibliography}

The first author is an Ethiopian, was born in 1976 at Addis Ababa. He has got his B.Sc in Agriculture (Plant Science) from Alemaya (Haramaya) University in 2001 and his M.Sc at Addis Ababa University in the field of Biology specialized with applied genetics in 2008. He served Ethiopian Institute of Agricultural Research (EIAR) for 16 years and currently he is a coordinator of oilseeds research program. The second author is also an Ethiopian, a lecture of Addis Ababa University and currently he is PostDoc fellow for TEAGASC- the Agriculture, and Food Development Authority, Ireland. The third author is German in citizen and has been working with the above two authors with CIDA-Funded Project for two years since 2007. He is a senior scientist and head of Global initiatives at the Crop Trust, Germany.

Table 1. Noug accessions collected from various areas of major regions of Ethiopia in 2007 and 2008

\begin{tabular}{|c|c|c|c|c|c|c|c|}
\hline S.No & $\begin{array}{c}\text { Acc. } \\
\text { designation }\end{array}$ & $\begin{array}{c}\text { Altitude } \\
\text { (m) }\end{array}$ & $\begin{array}{l}\text { Region of } \\
\text { collection }\end{array}$ & S.No & $\begin{array}{c}\text { Acc. } \\
\text { designation } \\
\end{array}$ & $\begin{array}{c}\text { Altitude } \\
\text { (m) }\end{array}$ & $\begin{array}{l}\text { Region of } \\
\text { collection } \\
\end{array}$ \\
\hline 1 & N08027 & 1251 & Amhara & 53 & N08040 & 3397 & Amhara \\
\hline 2 & N08031 & 1216 & Amhara & 54 & $\mathrm{RC}-2$ & 1804 & Oromiya \\
\hline 3 & N08051 & 1333 & Oromiya & 55 & N08003 & 2778 & Amhara \\
\hline 4 & N08028 & 1659 & Amhara & 56 & N07-005 & 1493 & Oromiya \\
\hline 5 & N08032 & 1690 & Tigray & 57 & N07-006 & 1487 & SNNP \\
\hline 6 & N08033 & 2149 & Tigray & 58 & N07-012 & 1494 & Oromiya \\
\hline 7 & N08034 & 1896 & Tigray & 59 & N07-013 & 1494 & Oromiya \\
\hline 8 & N08038 & 1716 & Amhara & 60 & N07-014 & 1787 & Oromiya \\
\hline 9 & N08055 & 1410 & Oromiya & 61 & N07-015 & 1525 & Oromiya \\
\hline 10 & N07-046 & 2544 & Amhara & 62 & N07-016 & 1525 & Oromiya \\
\hline 11 & N08001 & 2481 & Amhara & 63 & N07-033 & 1227 & Oromiya \\
\hline 12 & N08002 & 2612 & Amhara & 64 & N07-036 & 1343 & Oromiya \\
\hline 13 & N08039 & 2171 & Amhara & 65 & N07-037 & 1557 & Oromiya \\
\hline 14 & N08042 & 2917 & Amhara & 66 & N07-038 & 1557 & Oromiya \\
\hline 15 & N08043 & 2826 & Amhara & 67 & N08009 & 1500 & Amhara \\
\hline 16 & N08044 & 2531 & Oromiya & 68 & N08010 & 1276 & Amhara \\
\hline 17 & N07-025 & 1335 & Oromiya & 69 & N08011 & 1212 & Amhara \\
\hline 18 & N07-026 & 1414 & BSG & 70 & N07-003 & 1669 & Oromiya \\
\hline 19 & N07-027 & 1445 & $\mathrm{BSG}$ & 71 & N07-003 & 1669 & Oromiya \\
\hline 20 & N07-028 & 1293 & BSG & 72 & N07-004 & 1764 & Oromiya \\
\hline 21 & N07-029 & 1411 & $\mathrm{BSG}$ & 73 & N07-009 & 1635 & Oromiya \\
\hline 22 & N07-029 & 1411 & BSG & 74 & N07-010 & 1635 & Oromiya \\
\hline 23 & N07-030 & 1334 & BSG & 75 & N07-017 & 1763 & Oromiya \\
\hline 24 & N08012 & 1208 & Amhara & 76 & N07-018 & 1829 & Oromiya \\
\hline 25 & N08013 & 1484 & Amhara & 77 & N07-019 & 1829 & Oromiya \\
\hline 26 & N08016 & 872 & Amhara & 78 & N07-020 & 1832 & Oromiya \\
\hline 27 & N08017 & 872 & Amhara & 79 & N07-021 & 1832 & Oromiya \\
\hline 28 & N08018 & 820 & Amhara & 80 & N07-022 & 1672 & Oromiya \\
\hline 29 & N08019 & 770 & Amhara & 81 & N07-023 & 1521 & Oromiya \\
\hline 30 & N07-001 & 2022 & Oromiya & 82 & N07-023 & 1521 & Oromiya \\
\hline 31 & N07-001 & 2022 & Oromiya & 83 & N07-023 & 1521 & Oromiya \\
\hline 32 & N07-002 & 2070 & Oromiya & 84 & N07-024 & 1510 & Oromiya \\
\hline 33 & N07-011 & 1562 & Oromiya & 85 & N07-039 & 2203 & Oromiya \\
\hline 34 & N07-031 & 1482 & BSG & 86 & N07-040 & 1846 & Oromiya \\
\hline 35 & N07-032 & 1462 & BSG & 87 & N07-042 & 1909 & Amhara \\
\hline 36 & N08014 & 1784 & Amhara & 88 & N07-043 & 1952 & Amhara \\
\hline 37 & N08020 & 1929 & Amhara & 89 & N07-044 & 2056 & Amhara \\
\hline 38 & N08021 & 1878 & Amhara & 90 & N07-045 & 1868 & Amhara \\
\hline 39 & N08022 & 1833 & Amhara & 91 & N08005 & 2143 & Amhara \\
\hline 40 & N08023 & 1833 & Amhara & 92 & N08006 & 2086 & Amhara \\
\hline 41 & N08024 & 1762 & Amhara & 93 & N08007 & 2086 & Amhara \\
\hline 42 & N08026 & 2116 & Amhara & 94 & N08008 & 2078 & Amhara \\
\hline 43 & N08029 & 1842 & Amhara & 95 & $\mathrm{RC}-12$ & 1569 & Oromiya \\
\hline 44 & N08030 & 2462 & Amhara & 96 & RC-19 & 1868 & Amhara \\
\hline
\end{tabular}




\begin{tabular}{|l|l|l|l|l|l|l|l|}
\hline S.No & \multicolumn{1}{|c|}{$\begin{array}{c}\text { Acc. } \\
\text { designation }\end{array}$} & $\begin{array}{c}\text { Altitude } \\
(\mathbf{m})\end{array}$ & $\begin{array}{c}\text { Region of } \\
\text { collection }\end{array}$ & S.No & $\begin{array}{c}\text { Acc. } \\
\text { designation }\end{array}$ & $\begin{array}{c}\text { Altitude } \\
(\mathbf{m})\end{array}$ & $\begin{array}{c}\text { Region of } \\
\text { collection }\end{array}$ \\
\hline 45 & N08035 & 2597 & Amhara & 97 & RC-3 & 1804 & Oromiya \\
\hline 46 & N08036 & 1591 & Amhara & 98 & RC-4 & 1832 & Oromiya \\
\hline 47 & N08037 & 2099 & Amhara & 99 & RC-9 & 1636 & Oromiya \\
\hline 48 & N08041 & 2375 & Amhara & 100 & N08004 & 3062 & Amhara \\
\hline 49 & N08046 & 2057 & Oromiya & 101 & Fogera & - & - \\
\hline 50 & N08047 & 1887 & Oromiya & 102 & Esete & - & - \\
\hline 51 & N08048 & 2004 & Oromiya & 103 & Kuyu & - & - \\
\hline 52 & N08049 & 2006 & Oromiya & 104 & Shambu & - & - \\
\hline
\end{tabular}

Note: $\mathrm{BSG}=$ Benishangul Gumuz, $\mathrm{SNNP}=$ South Nation and Nationalities People

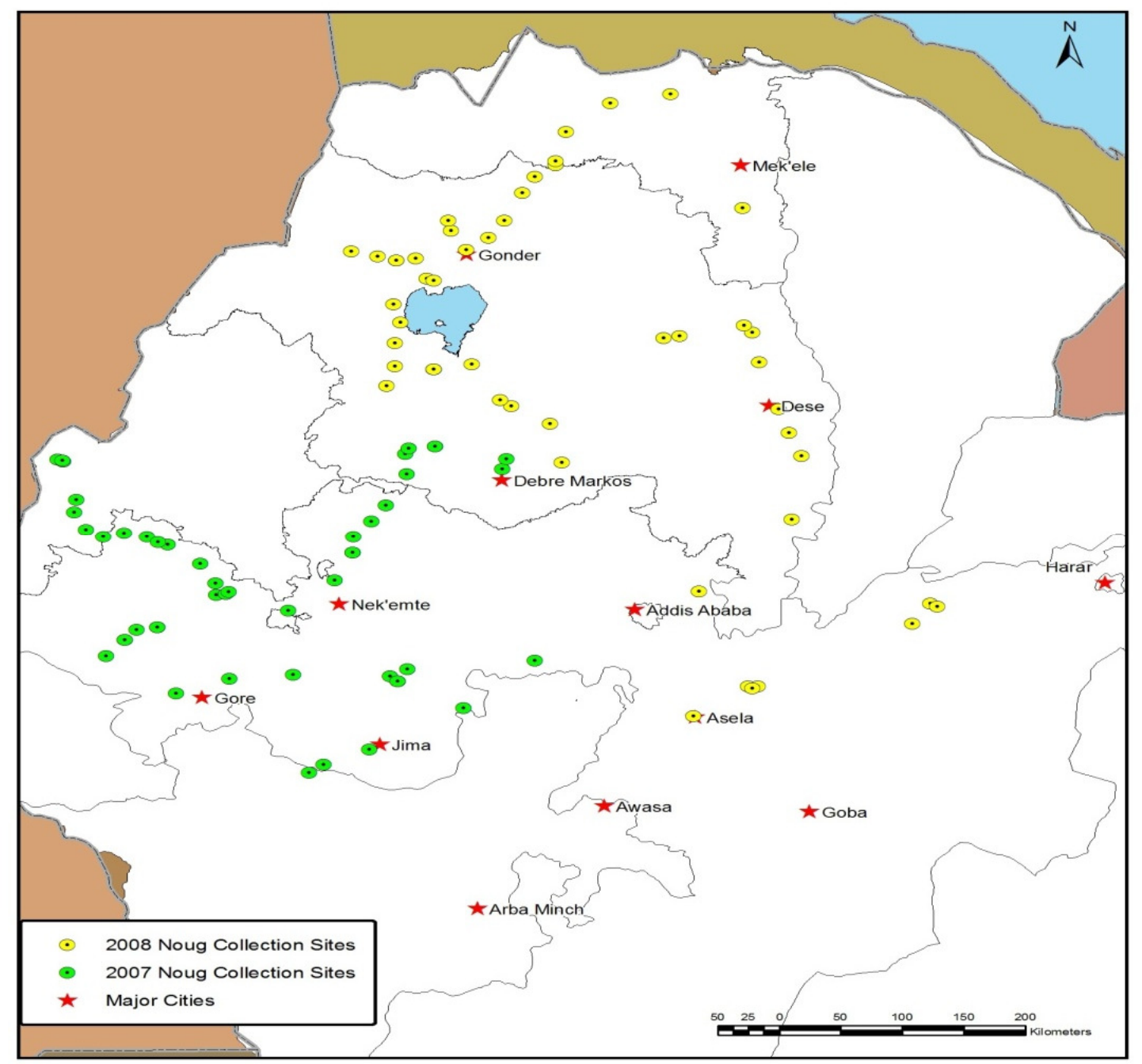

Fig.1: Noug collections made in year 2007 are shown in green, those made in 2008 are shown in yellow. 

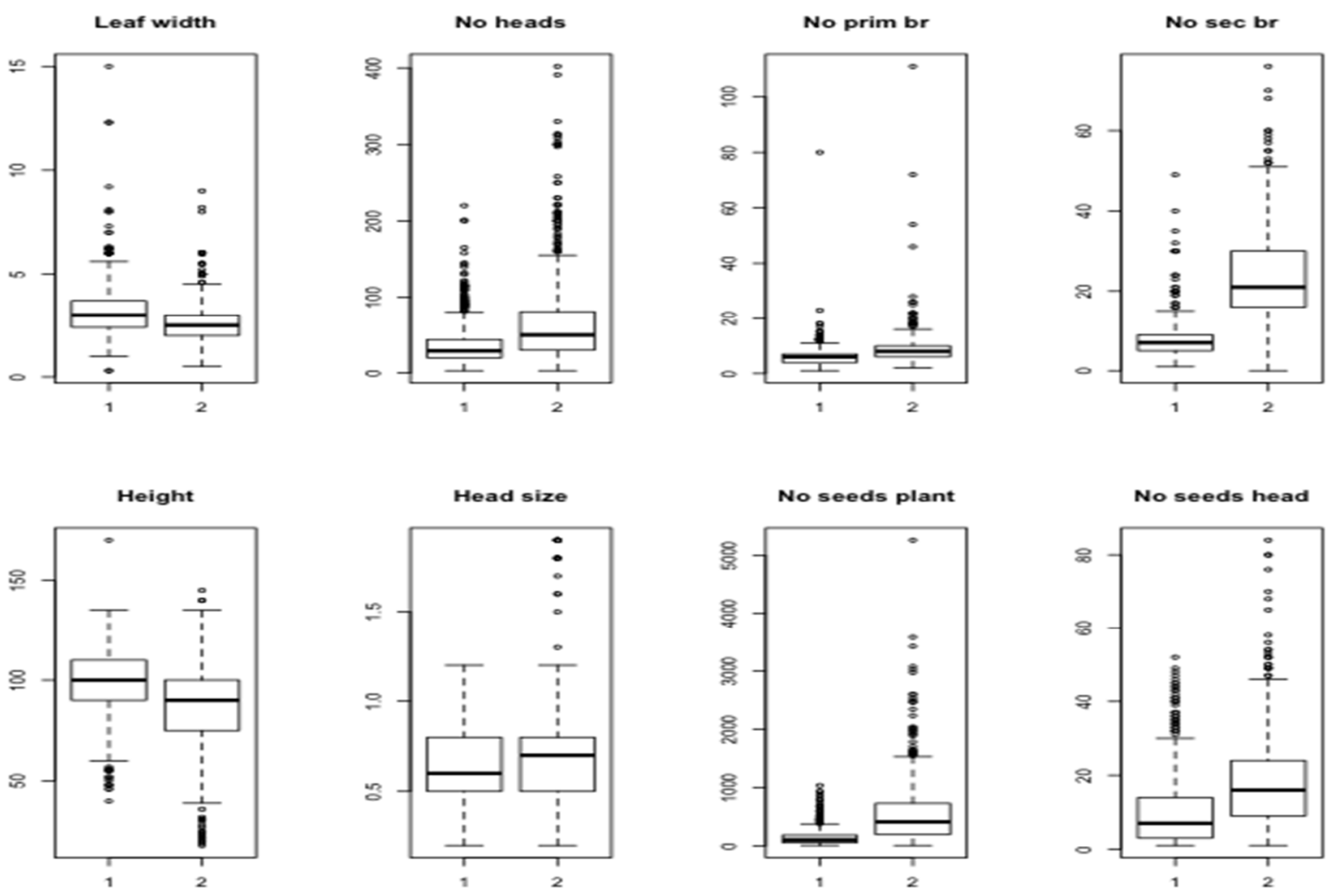

Fig.2: Boxplots showing differences between the two sites, Holetta (1) and Ginchi (2) for several phenotypic traits that were assessed.

Table 2. Phenotypic trait correlations of selected traits at Holetta and Ginchi

\begin{tabular}{|c|c|c|c|c|c|c|c|}
\hline $\begin{array}{l}\text { Tra } \\
\text { its }\end{array}$ & NH & NPB & NSB & PH & HS & NSPP & NSPH \\
\hline NH & $1.00 / 1.00$ & - & - & - & - & - & - \\
\hline $\begin{array}{l}\text { NP } \\
\text { B }\end{array}$ & $\begin{array}{l}0.6515 * * * / 0 \\
.4085 * * *\end{array}$ & $1.00 / 1.00$ & - & - & - & - & - \\
\hline $\begin{array}{l}\text { NS } \\
\text { B }\end{array}$ & $\begin{array}{l}0.355 * * * / 0 \\
6466 * * *\end{array}$ & $\begin{array}{l}\mathbf{0 . 3 3 2} * * * / \mathbf{0} \\
\mathbf{5 7 5 8} * * *\end{array}$ & $1.00 / 1.00$ & - & - & - & - \\
\hline PH & $\begin{array}{l}0.1705 * * * / 0 \\
.484 * * *\end{array}$ & $\begin{array}{l}0.143 * * * / 0 \\
357 * * *\end{array}$ & $\begin{array}{l}0.1251 * * * / 0 \\
.3923 * * *\end{array}$ & $1.00 / 1.00$ & - & - & - \\
\hline HS & $\begin{array}{l}- \\
0.0008 N S / 0 . \\
005 N S\end{array}$ & $\begin{array}{l}0.0235 \mathrm{NS} / 0 . \\
05218 \mathrm{NS}\end{array}$ & $\begin{array}{l}0.0409 N S / 0 \\
.0861 * *\end{array}$ & $\begin{array}{l}0.0174 \mathrm{NS} / 0 \\
.1325 * * *\end{array}$ & $1.00 / 1.00$ & - & - \\
\hline NS & $0.4413 * * * /$ & $0.368 * * * / 0$ & $0.2118 * * * / 0$ & $0.0505 N S / 0$ & - & $1.00 / 1.00$ & - \\
\hline PP & $0.2406 * * *$ & $2656 * * *$ & $.2098 * * *$ & $.0485 \mathrm{NS}$ & $\begin{array}{l}0.0158 N S / 0 \\
.0143 N S\end{array}$ & & \\
\hline NS & $0.0083 \mathrm{NS} /-$ & $0.0359 \mathrm{NS} /-$ & $0.049 \mathrm{NS} /-$ & $0.024 N S /-$ & $0.0758 * * /-$ & $0.3652 * * * / 0$ & $1.00 / 1.00$ \\
\hline PH & $0.1111 * *$ & 0.0481NS & $0.0743 *$ & $0.1831 * * *$ & $0.0235 N S$ & $.1373 * * *$ & \\
\hline TS & $0.0666 \mathrm{NS} /-$ & $0.1743 N S /-$ & $0.145 N S / 0$ & $0.2947 * / 0.1$ & $0.0666 \mathrm{NS} / 0$ & - & $0.0714 N S /-$ \\
\hline $\mathbf{W}$ & $0.1677 N S$ & $0.0463 \mathrm{NS}$ & $2769 * *$ & $731 N S$ & $.4582 * * *$ & $\begin{array}{l}\text { 0.0884NS/0. } \\
06441 \text { NS }\end{array}$ & $0.785 N S$ \\
\hline
\end{tabular}

Note : Values stated above as Holetta followed by Ginchi separated by slash '/, $\quad *$, ** and *** denote the strength significance as significant, highly significant and very highly significant, respectively at $\mathrm{P}<0.05$. $\mathrm{NH}$ : Number of heads, NPB: Number of primary branch, NSB: Number of secondary branch, PH: plant height, HS: head size, NSPP: Number of seed per plant, NSPH: Number of seed per head, TSW: Thousands Seed Weight. 


\section{Principal Coordinates}

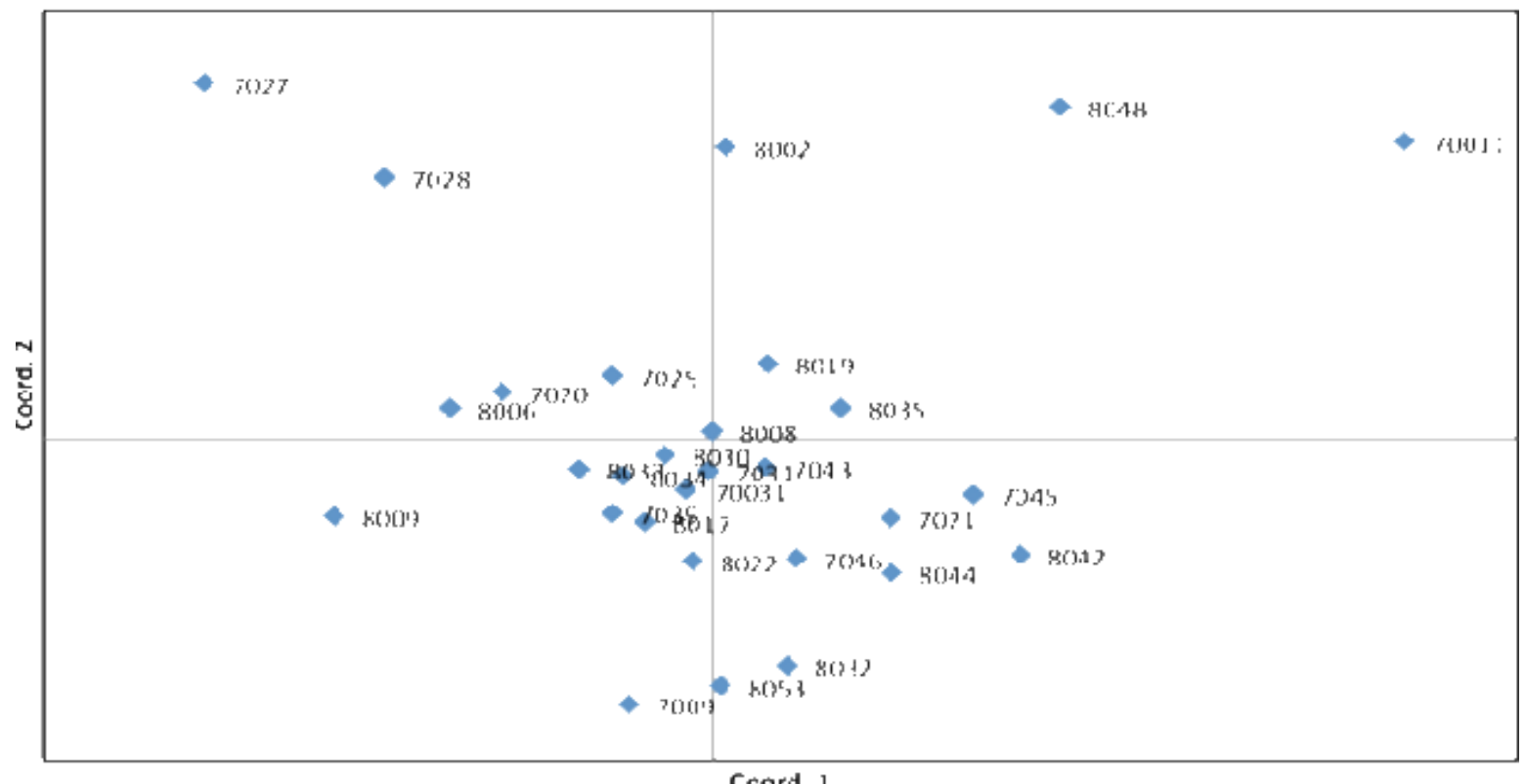

Fig.3 Principal coordinates analysis based on a Fst distance matrix, which has been calculated from the generated genotypic data.

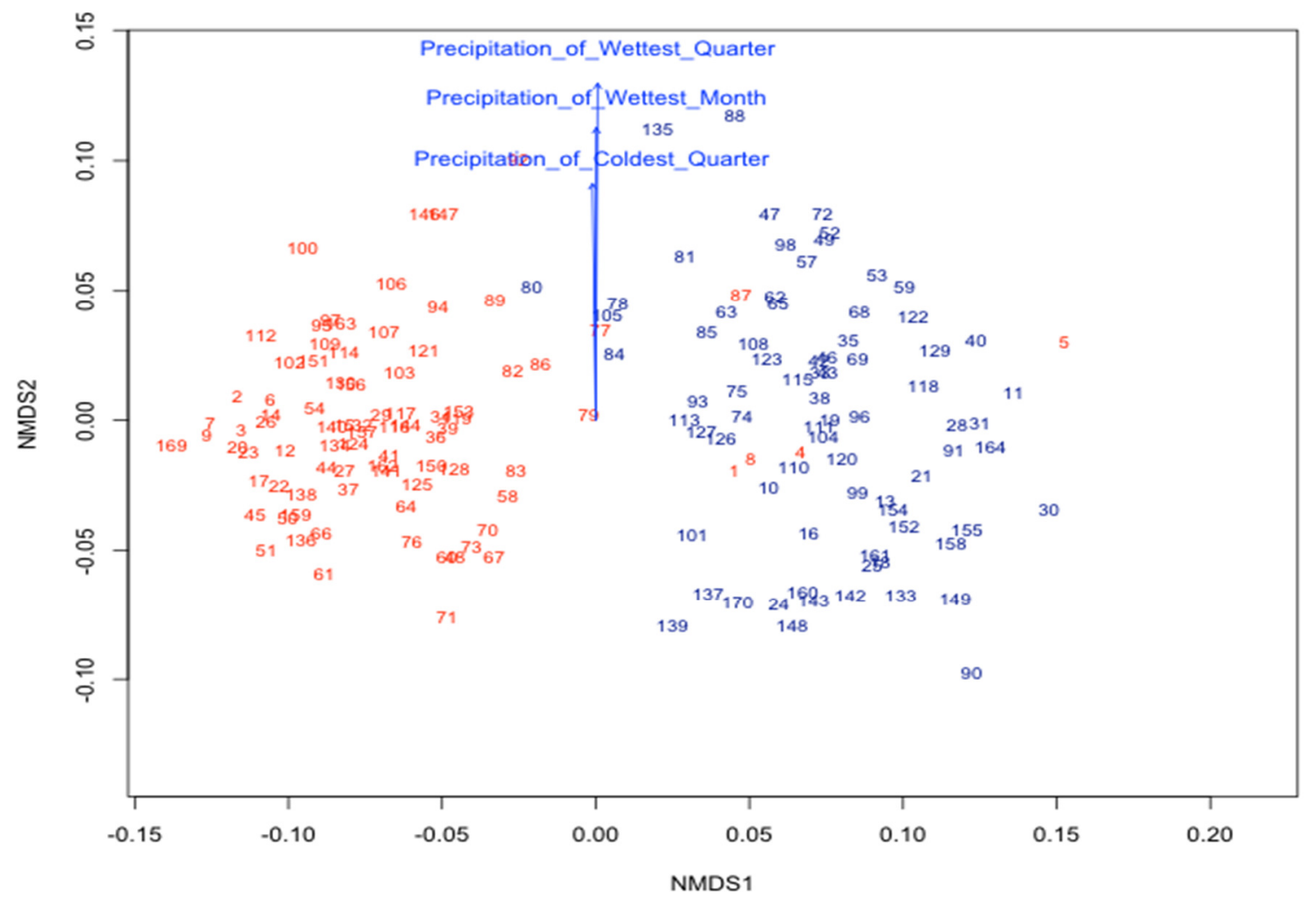

Fig. 4. NMDS analysis of phenotypic data of both sites (red = site 1 and blue $=$ site 2$)$ showing correlations with environmental variables. 


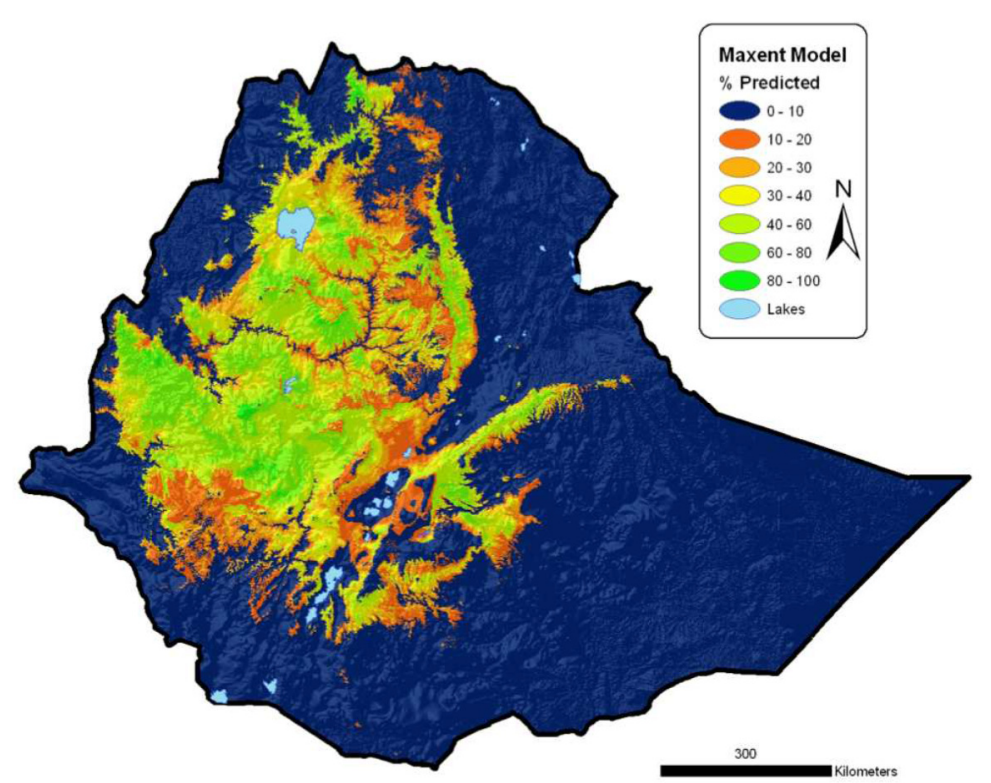

Fig.5: Map of Ethiopia showing the predicted agro-ecological niche for noug.

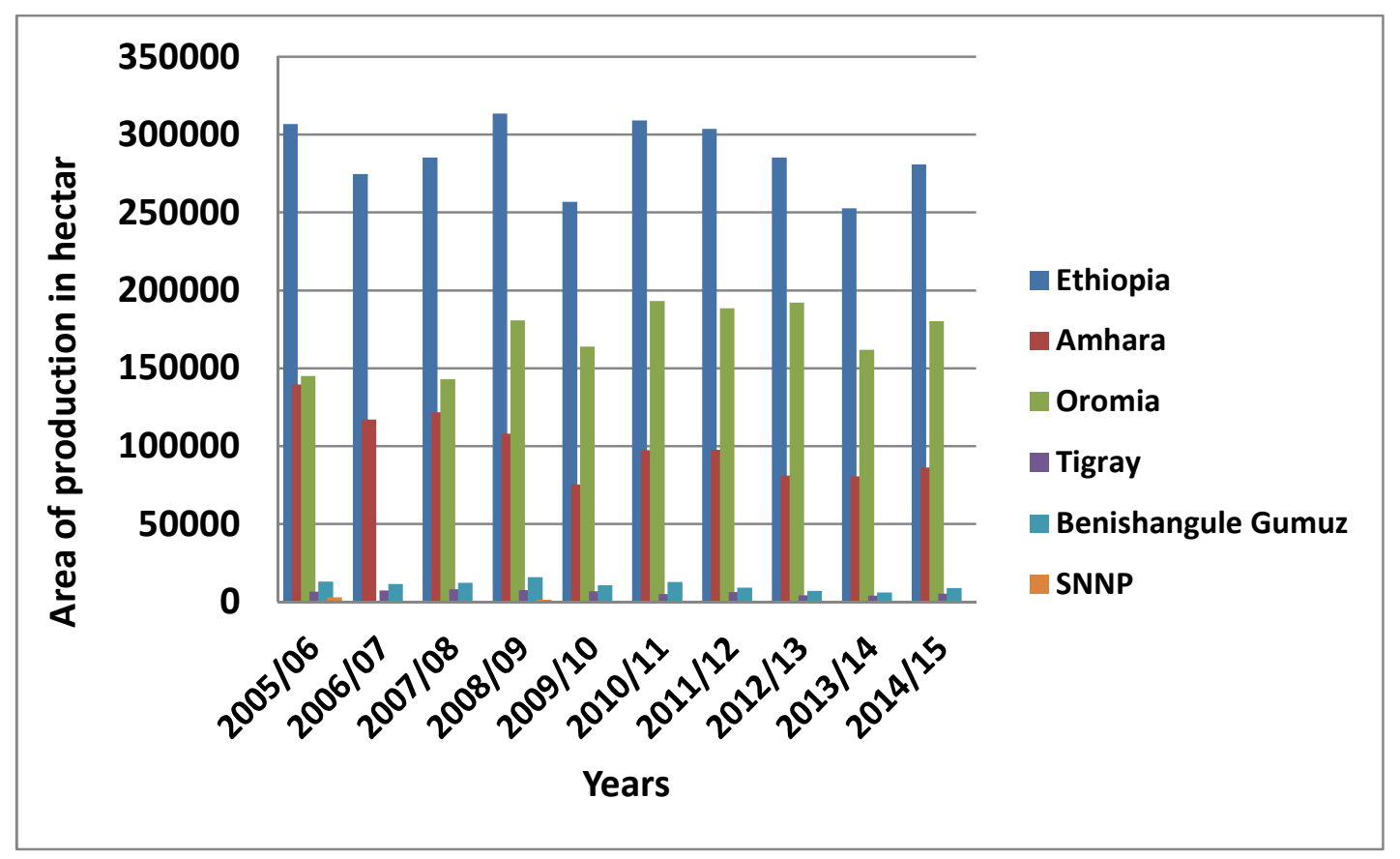

Fig 6. Area of production of noug in Ethiopia for the last 10 years 


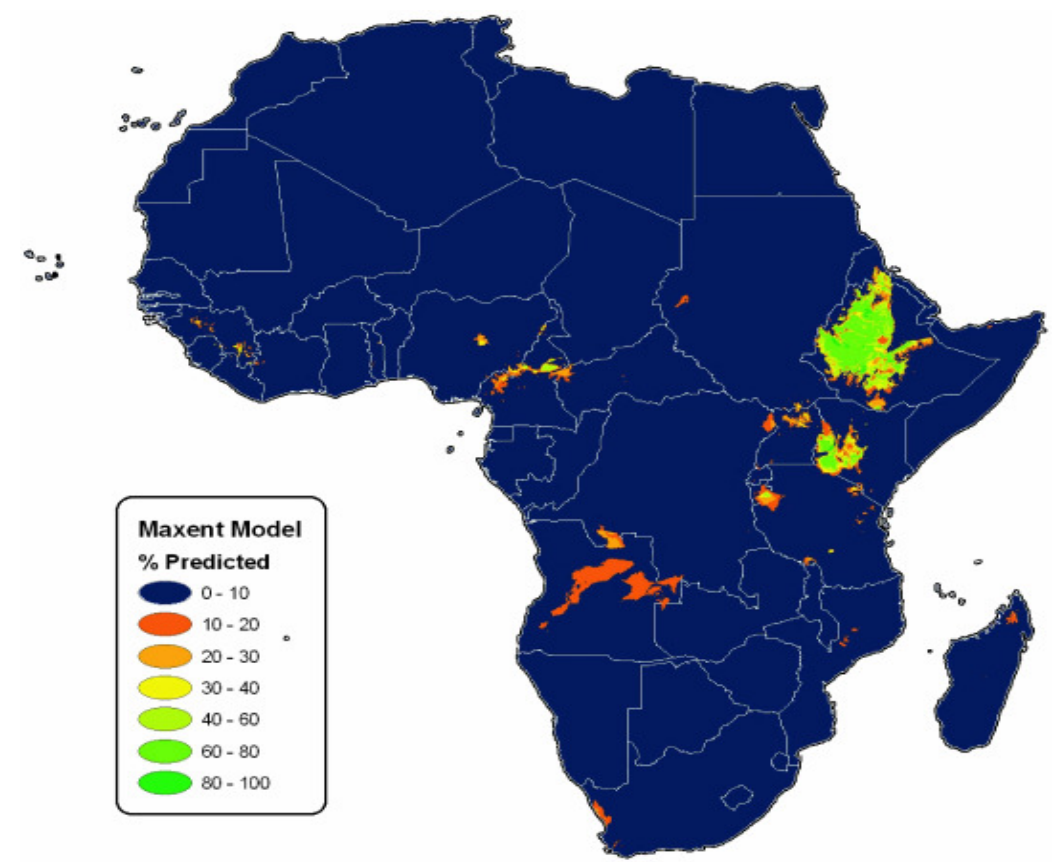

Fig.7. Map of Africa, indicating which areas would be suitable for noug production.

Table 3. Noug genotypes identified as potential interest to breeding efforts

\begin{tabular}{|c|c|}
\hline Useful traits & Collections with useful trait \\
\hline $\begin{array}{l}\text { Maximum number of heads } \\
\text { (observed range: } 8 \text { to } 144 \text { heads; mean } \\
\text { value: } 50 \text { ) }\end{array}$ & $\begin{array}{l}\text { N07-024 (144); N08-019 (136); N07-029-1 (135); } \\
\text { N07-032 (126) and N07-026 (125) }\end{array}$ \\
\hline $\begin{array}{l}\text { Height }- \text { shortest } \\
\text { (observed range: } 24 \mathrm{~cm} \text { to } 117 \mathrm{~cm} \text {; mean value: } 93 \mathrm{~cm} \text { ) }\end{array}$ & $\begin{array}{l}\mathrm{N} 08-037(24 \mathrm{~cm}) ; \mathrm{N} 08-034(27 \mathrm{~cm}) ; \mathrm{N} 08-043(54 \mathrm{~cm}) ; \\
\text { N08-034 }(57 \mathrm{~cm}) ; \mathrm{N} 08-037(58 \mathrm{~cm})\end{array}$ \\
\hline $\begin{array}{l}\text { Number of seeds per plant } \\
\text { (observed range: } 34 \text { to } 1465 \text {; mean value: } 337 \text { ) }\end{array}$ & $\begin{array}{l}\text { N07-015 (1465); N07-020 (1008); N07-004 (1385); } \\
\text { N07-002 (1134) and N08-001 (994) }\end{array}$ \\
\hline Number of seeds per head & N08-001 (52); N07-012 (32); N08-042 \\
\hline $\begin{array}{l}\text { (observed range: } 0 \text { to } 52 ; \text { mean value: } 14 \text { ) } \\
1000 \text { seed weight } \\
\text { (observed range: } 0.7 \text { to } 4.9 \mathrm{~g} ; \text { mean value: } 3.1\end{array}$ & $\begin{array}{l}\text { N08-008 (34); N07-005 (32); } \\
\text { N08-028 (4.9); N08-48 (4.9); N08-017 (4.8); N08- } \\
026 \text { (4.8) and N08-030 (4.8) }\end{array}$ \\
\hline
\end{tabular}

\section{Acknowledgements}

This work was supported by CIDA Funded Noug Project to which the authors are highly grateful. We thank Mr. Mekonen Gemechu and Mrs. Samra Daniel for their assistance in field works. 